\title{
Cell-division pattern and phylogenetic analyses of a new ciliate genus Parasincirra n. g. (Protista, Ciliophora, Hypotrichia), with a report of a new soil species, $P$. sinica $n$. sp. from northwest China
}

\author{
Jiyang Ma ${ }^{1,2+}$, Yan Zhao ${ }^{3 \dagger}$, Tengyue Zhang ${ }^{1}$, Chen Shao ${ }^{2 *} \mathbb{D}$, Khaled A. S. Al-Rasheid ${ }^{4}$ and Weibo Song ${ }^{1,2,5}$
}

\begin{abstract}
Background: Ciliated protists, a huge assemblage of unicellular eukaryotes, are extremely diverse and play important ecological roles in most habitats where there is sufficient moisture for their survivals. Even though there is a growing recognition that these organisms are associated with many ecological or environmental processes, their biodiversity is poorly understood and many biotopes (e.g. soils in desert areas of Asia) remain largely unknown. Here we document an undescribed form found in sludge soil in a halt-desert inland of China. Investigations of its morphology, morphogenesis and molecular phylogeny indicate that it represents a new genus and new species, Parasincirra sinica n. g., $\mathrm{n}$. sp.

Results: The new, monotypic genus Parasincirra n. g. is defined by having three frontal cirri, an amphisiellid median cirral row about the same length as the adoral zone, one short frontoventral cirral row, cirrus III/2 and transverse cirri present, buccal and caudal cirri absent, one right and one left marginal row and three dorsal kineties. The main morphogenetic features of the new taxon are: (1) frontoventral-transverse cirral anlagen II to VI are formed in a primary mode; (2) the amphisiellid median cirral row is formed by anlagen $\mathrm{V}$ and $\mathrm{VI}$, while the frontoventral row is generated from anlage IV; (3) cirral streaks IV to VI generate one transverse cirrus each; (4) frontoventral-transverse cirral anlage II generates one or two cirri, although the posterior one (when formed) will be absorbed in late stages, that is, no buccal cirrus is formed; (5) the posterior part of the parental adoral zone of membranelles is renewed; (6) dorsal morphogenesis follows a typical Gonostomum-pattern; and (7) the macronuclear nodules fuse to form a single mass. The investigation of its molecular phylogeny inferred from Bayesian inference and Maximum likelihood analyses based on small subunit ribosomal DNA (SSU rDNA) sequence data, failed to reveal its exact systematic position, although species of related genera are generally assigned to the family Amphisiellidae Jankowski, 1979. Morphological and morphogenetic differences between the new taxon and Uroleptoides Wenzel, 1953, Parabistichella Jiang et al., 2013, and other amphisiellids clearly support the validity of Parasincirra as a new genus. The monophyly of the family Amphisiellidae is rejected by the AU test in this study.
\end{abstract}

\footnotetext{
*Correspondence: shaochen@snnu.edu.cn

${ }^{\dagger}$ Jiyang Ma and Yan Zhao contributed equally

${ }^{2}$ Laboratory of Protozoological Biodiversity and Evolution in Wetland,

College of Life Sciences, Shaanxi Normal University, Xi'an 710119, China

Full list of author information is available at the end of the article
}

(C) The Author(s) 2021. Open Access This article is licensed under a Creative Commons Attribution 4.0 International License, which permits use, sharing, adaptation, distribution and reproduction in any medium or format, as long as you give appropriate credit to the original author(s) and the source, provide a link to the Creative Commons licence, and indicate if changes were made. The images or other third party material in this article are included in the article's Creative Commons licence, unless indicated otherwise in a credit line to the material. If material is not included in the article's Creative Commons licence and your intended use is not permitted by statutory regulation or exceeds the permitted use, you will need to obtain permission directly from the copyright holder. To view a copy of this licence, visit http://creativecommons.org/licenses/by/4.0/. The Creative Commons Public Domain Dedication waiver (http://creativeco mmons.org/publicdomain/zero/1.0/) applies to the data made available in this article, unless otherwise stated in a credit line to the data. 
Conclusions: The critical character of the family Amphisiellidae, i.e., the amphisiellid median cirral row, might result from convergent evolution in different taxa. Amphisiellidae are not monophyletic.

Keywords: New species, Morphology, Morphogenesis, Parasincirra, SSU rDNA phylogeny

\section{Background}

Recent faunistic studies have revealed numerous new taxa of hypotrichous ciliates suggesting that this group is more diverse than previously supposed [1-8]. Furthermore, much work has been carried out on the morphogenesis and molecular phylogeny of hypotrichs, which has led to a better understanding of their systematics and evolutionary relationships [9-17].

Among these, the order Stichotrichida Fauré-Fremiet, 1961 is one of the most confused and diverse ciliate groups in terms of both its taxonomy and phylogeny [18]. One of its largest families, Amphisiellidae Jankowski, 1979, is characterised by the possession of an amphisiellid median cirral row derived from two or three, rather than one, frontoventral-transverse cirral anlagen. Most amphisiellids occur in terrestrial habitats, although some are marine $[15,19,20]$. In the present study, we present a new amphisiellid collected from sludge soil in a flood drain in Lanzhou, China (Fig. 1). Observations of its morphology and morphogenesis, both in vivo and after protargol staining, demonstrate that it represents a novel genus, Parasincirra n. g., of the family Amphisiellidae. The SSU rDNA of the new isolate was sequenced and its molecular phylogeny was analyzed.

\section{Results}

\section{ZooBank registration}

Present work: urn:lsid:zoobank.org:pub:51385DEC-9698435A-AB33-C3EB91CBE777.

\section{Establishment of the new genus Parasincirra n. g. ZooBank registration}

Parasincirra n. g.: urn:lsid:zoobank.org:act:ACDEF2AAF1A6-4D80-B0F9-115603AB6B3F.

Diagnosis Amphisiellidae with elongate body. Three frontal cirri. Amphisiellid median cirral row about same length as adoral zone. One short frontoventral cirral row. Cirrus III/2 and transverse cirri present. One right and one left marginal row. Three dorsal kineties. Caudal cirri and buccal cirrus lacking.

Type species Parasincirra sinica n. sp.

Etymology Composite of the Greek prefix para- (close to; related; deviating) and suffix (-sincirra) of the genus name Hemisincirra Hemberger, 1985. This indicates that Parasincirra has a cirral pattern similar to that of Hemisincirra. Feminine gender.

Remarks We do not assign Hemisincirra interrupta (Foissner, 1982) Foissner in Berger, 2001 and H. vermicularis Hemberger, 1985 to our new genus Parasincirra although both species also lack a buccal cirrus. The main reasons are that either the ontogenetic or the molecular information are unknown for these two species.

\section{Parasincirra sinica n. sp. ZooBank registration}

Parasincirrasinican.sp.:urn:lsid:zoobank.org:act:3F05A977F059-4108-895F-CA98FF59E8DE.

Diagnosis Size in vivo 90-160 $\mu \mathrm{m} \times 20-40 \mu \mathrm{m}$. Body slender, fusiform to vermiform, with pointed posterior end. Two to six (mostly four) macronuclear nodules. Contractile vacuole located slightly ahead of mid-body. Cortical granules about $0.5 \mu \mathrm{m}$ across, colourless and grouped around dorsal ciliary organelles. Three frontal cirri and one parabuccal cirrus; frontoventral row constantly with two cirri; two to four transverse cirri. Amphisiellid median cirral row terminates behind level of cytostome, invariably composed of four cirri. One left and one right marginal row, composed of 34-52 and 34-53 cirri respectively. Three bipolar dorsal kineties. Adoral zone composed of 14-19 membranelles. Soil habitat.

Type material One protargol-stained slide (no. MJY2017043001B) with the holotype specimen and two paratype slides (no. MJY2017043001A, C) were deposited in the Laboratory of Protozoological Biodiversity and Evolution in Wetland, Shaanxi Normal University, China.

Type locality Flood drain, Lanzhou (36 $03^{\prime} \mathrm{N} ; 103^{\circ} 49^{\prime}$ E), China.

Etymology The species-group name sinica means the species was first discovered in China.

Morphological description Body 90-160 $\mu \mathrm{m} \times 20-40 \mu \mathrm{m}$ in vivo $(\mathrm{n}=6)$ with a ratio of length to width of about 3.5:1-7.5:1; protargol-stained cells $120 \mu \mathrm{m} \times 30 \mu \mathrm{m}$ on average with a ratio of length to width of about 4:1. Generally slender, almost fusiform to vermiform, non-contractile but highly flexible, and thus cell outline variable, i.e., sigmoidal or curved (Fig. 2d). Anterior end narrowly rounded and posterior end more or less tapered to form a pointed tail that is more flexible and contractile than the rest of the cell (Fig. 2a, d, g, h); tail unrecognisable in protargol preparations (Fig. 2e, f, i). Dorsoventrally flattened 


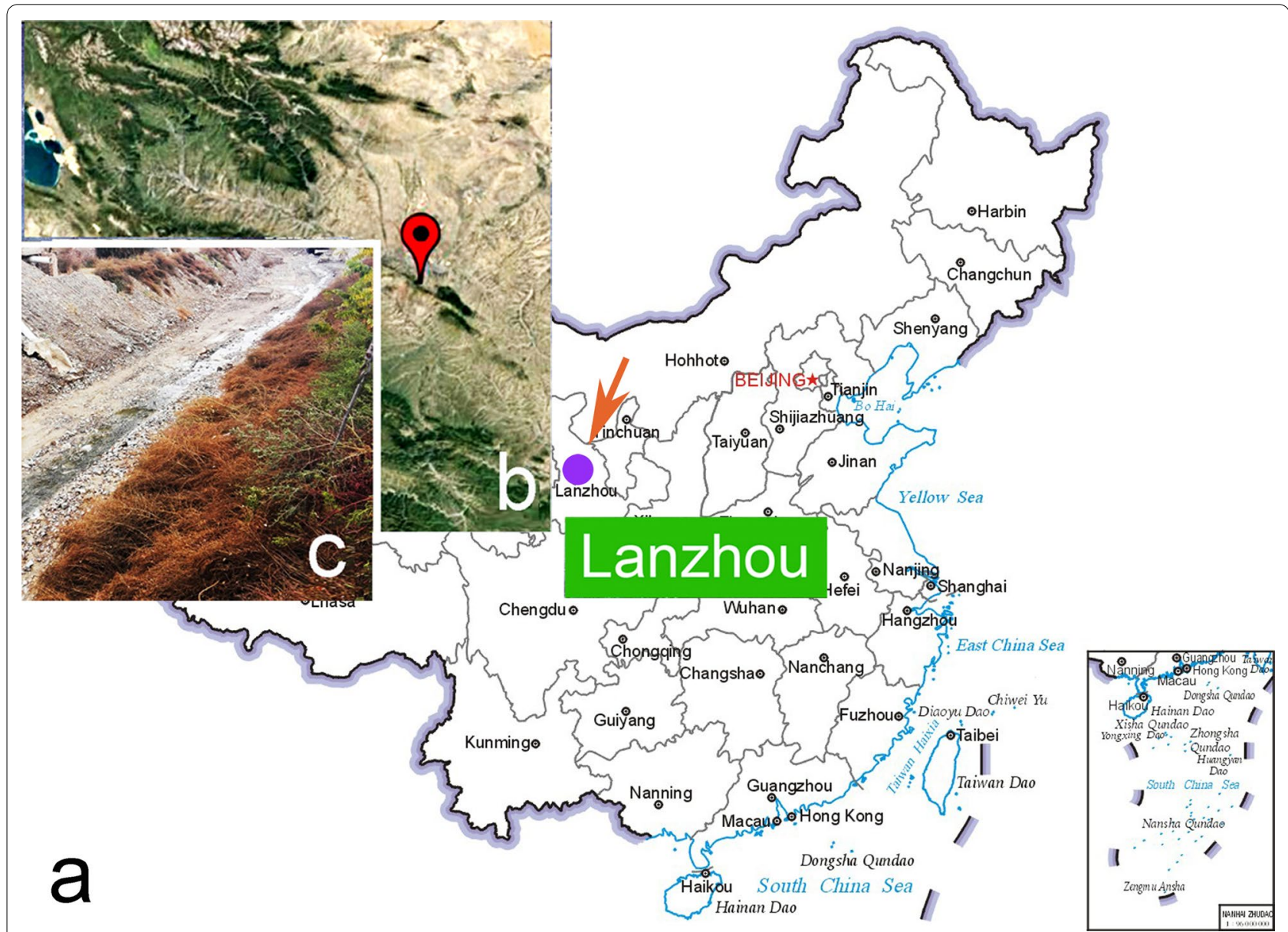

Fig. 1 a-c Locations of the sample sites. a, b The map of China from the MAP WORLD (www.tianditu.gov.cn, drawing review number: GS (2019) 1673) (a) and portion of Google Map (b), showing the location of Lanzhou, China ( $\left.36^{\circ} 03^{\prime} \mathrm{N} ; 103^{\circ} 49^{\prime} \mathrm{E}\right)$. c Showing the area surrounding the flood drain from where the sample containing Parasincirra sinica n. sp. was collected

up to 2:1. Usually four (2-6) macronuclear nodules arranged along or slightly left of mid-line, behind buccal vertex; one to three, on average two, micronuclei attached, or near to, macronuclear nodules. Macronuclear nodules ellipsoidal, about 9-19 $\mu \mathrm{m} \times 4-10 \mu \mathrm{m}$ after protargol staining (Fig. 2j). Micronuclei about $2.9 \mu \mathrm{m} \times 2.4 \mu \mathrm{m}$ after protargol staining. One contractile vacuole measuring about $13 \mu \mathrm{m}$ in diameter in diastole, positioned near left margin, contracting at intervals of $10 \mathrm{~s}$ (Fig. 2g, h). Cortical granules colourless, globular, about $0.5 \mu \mathrm{m}$ in diameter, distributed around dorsal ciliary organelles, also visible in protargol preparations (Fig. 2c, j, m). Cytoplasm colourless to greyish, often packed with numerous small lipid droplets. Locomotion mainly by slowly crawling on substrate and debris, sometimes jerking back and forth. When suspended, cells often swim continuously in circles.

Infraciliature as shown in Fig. 2b, e, f, i-l. Most somatic cirri relatively fine with cilia about $12-16 \mu \mathrm{m}$ long. Constantly three relatively stout frontal cirri in an almost transverse pseudo-row immediately behind several distal adoral membranelles, cilia about $15 \mu \mathrm{m}$ long. Amphisiellid median cirral row (ACR) short and consisting of four cirri; commences at about the level of the rightmost frontal cirrus (about 6\% down length of body), or slightly lower, terminates at about level of buccal vertex (about 21\% down length of body). Parabuccal cirrus (cirrus III/2) located at the level of the middle region of the paroral and endoral. Frontoventral row lies between the parabuccal cirrus and the ACR, invariably composed of two cirri; commences at about the level of the second cirrus in the ACR (about $8 \%$ down length of body) and terminates ahead of the third cirrus in the ACR (about 10\% down length of body). Three, rarely two or four, slightly subterminal transverse cirri, cilia of which are about $16 \mu \mathrm{m}$ long. Constantly one left and one right marginal row with 34-52 and 34-53 cirri, respectively (Table 1 ). Right marginal cirral row begins dorsolaterally at anterior end of cell 


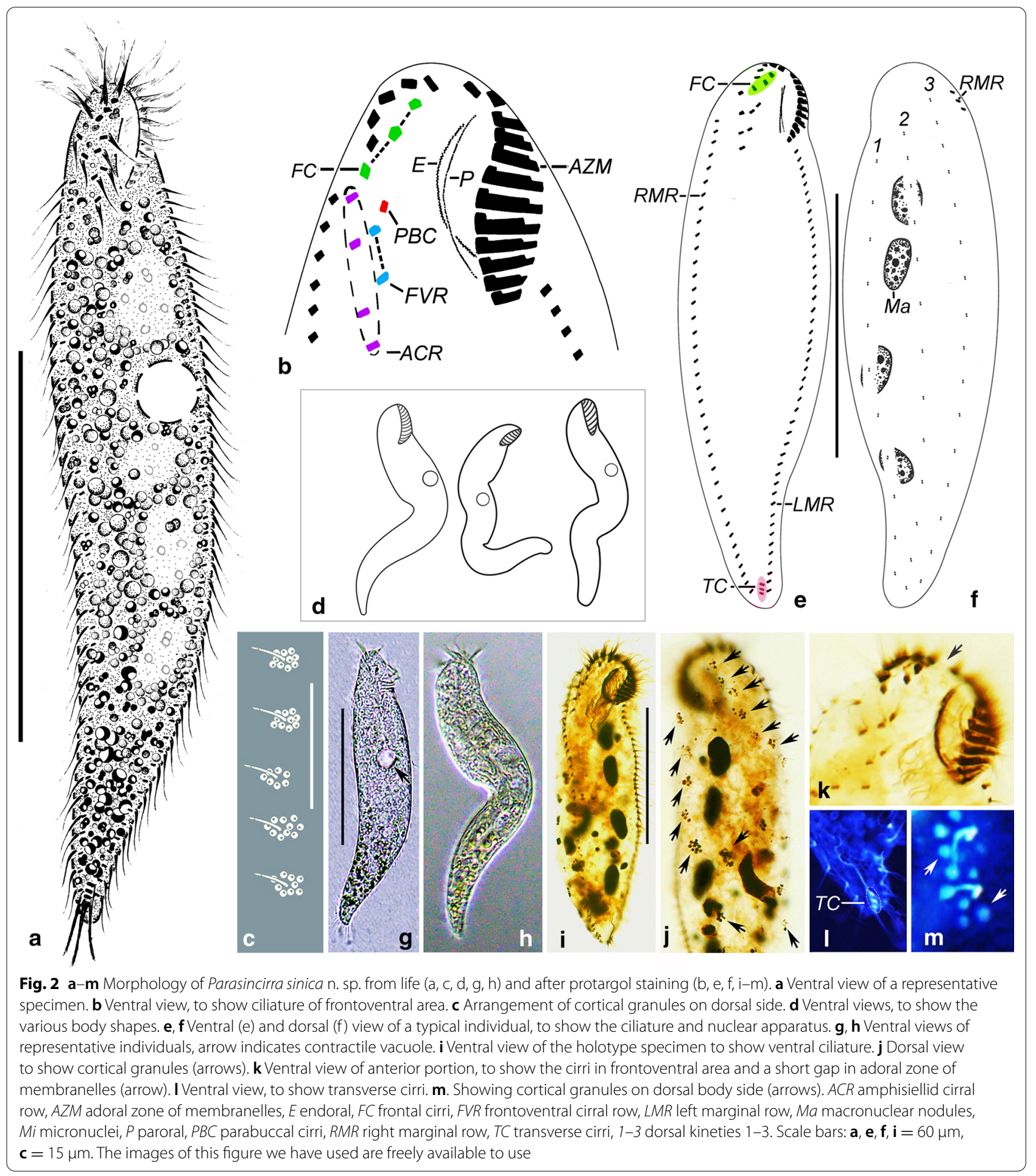

while left marginal cirral row begins at level of posterior end of adoral zone, both terminate caudally, not confluent posteriorly (Fig. 2b, e, i, k, l).

Three dorsal kineties arranged in Gonostomum-pattern, with cilia about $3 \mu \mathrm{m}$ in length, composed of about
13, 15 and 15 dikinetids, respectively, and arranged in a gradient; that is, kinety 3 commences apically, kinety 2 starts slightly behind kinety 3, while kinety 1 starts slightly behind kinety 2 . Each terminates at the posterior end of the body (Fig. 2f, j). 
Adoral zone of membranelles (AZM) shaped as in other amphisiellid species, terminates 11-20\% (average about 16\%) down length of body, comprising 14-19 membranelles. Cilia of distal membranelles about $13 \mu \mathrm{m}$ long. Buccal cavity small, endoral and paroral bending strongly and optically intersecting with each other at their lower or middle regions (Fig. 2b, e, i, k).

\section{Morphogenesis during binary fission Stomatogenesis}

Cortical morphogenesis in Parasincirra sinica n. sp. mainly occurs in two zones: an anterior field for the proter and a posterior field for the opisthe. In the opisthe, the first evidence of stomatogenesis during cell division is the appearance of groups of basal bodies on the cell surface, i.e., the opisthe's oral primordium, which is located in the end of the ACR, indicating that parental basal bodies are incorporated in the primordium (Fig. 3a). These groups subsequently merge by further proliferation of basal bodies forming a single anarchic field. Subsequently the new adoral membranelles organise posteriad (Figs. 3c, 5e). The anlage for the undulating membranes (anlage I) is formed to the right of the oral primordium (Figs. 3c, 5e). Later, the left frontal cirrus develops from the anterior end of the UM-anlage (Figs. $4 g, 5 j$ ). During the later stages, the differentiation of membranelles is completed forming the new oral structure for the opisthe. Subsequently, the UM-anlage gives rise to the leftmost frontal cirrus and the new endoral and paroral (Figs. 4a, b, 5n).

In the proter, several of the proximal membranelles dedifferentiate into sparsely distributed basal bodies which then differentiate into membranelles (Fig. 3c-e). The parental undulating membranes dedifferentiate into UM-anlage. The basic development of the UM-anlage then follows a similar pattern to that in the opisthe (Figs. 3b-e, g, 4a, 5d, e, m).

\section{Development of the frontoventral-transverse cirri}

The development of the somatic ciliature begins with the formation of the frontoventral-transverse cirral anlagen (FVT-anlagen). Initially, the FVT-anlagen appear as a small group of basal bodies (Fig. 3a). The

Table 1 Morphometric characteristics of Parasincirra sinica n. sp

\begin{tabular}{|c|c|c|c|c|c|c|c|c|}
\hline Character $^{\mathbf{a}}$ & HT & Min & Max & Mean & $M$ & SD & CV & $\mathbf{n}$ \\
\hline Body, length & 105 & 81 & 152 & 119.7 & 115 & 18.3 & 15.3 & 25 \\
\hline Body, width & 29 & 18 & 47 & 30.3 & 31 & 6.3 & 21.0 & 25 \\
\hline Body, length: width ratio & 3.57 & 2.29 & 7.59 & 4.12 & 3.79 & 1.13 & 27.35 & 25 \\
\hline AZM, length & 16 & 13 & 24 & 19.1 & 19 & 2.5 & 13.0 & 25 \\
\hline AZM, length: body length ratio & 0.16 & 0.11 & 0.20 & 0.16 & 0.16 & 0.02 & 13.07 & 25 \\
\hline AZM, number & 15 & 14 & 19 & 15.6 & 15 & 1.3 & 8.1 & 25 \\
\hline Paroral, length & 15 & 8 & 16 & 12.4 & 12 & 2.4 & 19.3 & 15 \\
\hline Endoral, length & 13 & 8 & 15 & 11.0 & 11 & 2.1 & 18.8 & 15 \\
\hline PBC, number & 1 & 1 & 1 & 1.0 & 1 & 0 & 0 & 25 \\
\hline FVR, number & 2 & 2 & 2 & 2.0 & 2 & 0 & 0 & 25 \\
\hline ACR, cirri number & 4 & 4 & 4 & 4.0 & 4 & 0 & 0 & 25 \\
\hline Frontal cirri, number & 3 & 3 & 3 & 3.0 & 3 & 0 & 0 & 25 \\
\hline Left marginal cirri, number & 43 & 34 & 52 & 41.3 & 41 & 5.3 & 12.9 & 25 \\
\hline Right marginal cirri, number & 39 & 34 & 53 & 41.2 & 39 & 5.2 & 12.6 & 25 \\
\hline Transverse cirri, number & 3 & 2 & 4 & 3.1 & 3 & 0.5 & 16.0 & 25 \\
\hline Dorsal kineties, number & 3 & 3 & 3 & 3.0 & 3 & 0 & 0 & 25 \\
\hline Dikinetids in DK1, number & 10 & 10 & 17 & 12.5 & 12 & 2.3 & 18.7 & 15 \\
\hline Dikinetids in DK2, number & 15 & 13 & 18 & 14.9 & 15 & 1.5 & 10.3 & 15 \\
\hline Dikinetids in DK3, number & 16 & 11 & 18 & 14.5 & 14 & 2.2 & 15.0 & 15 \\
\hline Macronuclear nodules, number & 4 & 2 & 6 & 4.1 & 4 & 0.7 & 16.2 & 25 \\
\hline Macronuclear nodule, average length & 10 & 9 & 19 & 13.8 & 14 & 2.8 & 20.4 & 25 \\
\hline Macronuclear nodule, average width & 5 & 4 & 10 & 6.0 & 6 & 1.2 & 20.4 & 25 \\
\hline Micronuclei, number & 2 & 1 & 3 & 2.0 & 2 & 0.7 & 37.5 & 25 \\
\hline Micronuclear nodule, average length & 4 & 2 & 4 & 2.9 & 3 & 0.4 & 14.5 & 25 \\
\hline Micronuclear nodule, average width & 3 & 2 & 4 & 2.4 & 2 & 0.4 & 18.0 & 25 \\
\hline
\end{tabular}

$A C R$ amphisiellid median cirral row, $A Z M$ adoral zone of membranelles, $C V$ coefficient of variation in \%, DK dorsal kineties, FVR frontoventral cirral row, $H T$ holotype specimen, $M$ median, Max maximum, Mean arithmetic mean, Min minimum, $n$ sample size, $P B C$ parabuccal cirri, $S D$ standard deviation

a All data are based on protargol-stained specimens. Measurements in $\mu \mathrm{m}$ 
parental frontoventral cirri disaggregate and appear to in the formation of the FVT-anlagen. Later, five FVTanlagen are formed to the right of the UM-anlage in the proter as primary primordia (Figs. 3b, 5d). Then, the FVT-anlagen fragment in the middle to form two sets of anlagen, one set for the proter and the other for the opisthe (Figs. 3d, e, 5h, i). Subsequently, cirri segregate from anterior to posterior in the following manner: anlage I develops the frontal cirrus I/1 (leftmost frontal cirrus); anlage II produces the middle frontal cirrus; anlage III generates a parabuccal cirrus and the rightmost frontal cirrus; anlage IV contributes two cirri forming the short frontoventral cirral row; anlage $\mathrm{V}$ produces the posterior two cirri in the ACR; anlage
VI forms the anterior two cirri in the ACR; and anlagen IV-VI produce one transverse cirrus each (Figs. 4a, b, $5 \mathrm{~m}, \mathrm{p})$. Finally, the new cirri move to their final positions.

\section{Development of marginal rows and dorsal kineties}

Within every parental marginal row a few cirri near the anterior end, and a few others below the mid-body, differentiate to form two separate anlagen. The dorsal kineties develop by intrakinetal basal body proliferation, i.e. two anlagen develop in each parental row. Subsequently, the new marginal cirral rows and dorsal kineties develop and replace the old ones (Figs. 3d-h, $4 a-c, 5 g, h, j, m)$.

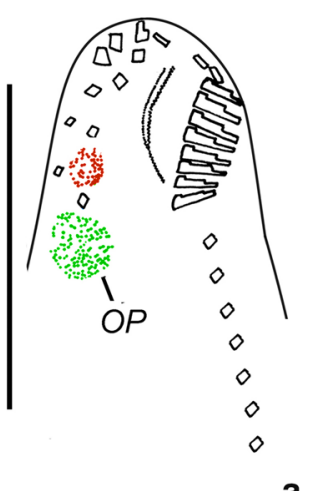

a

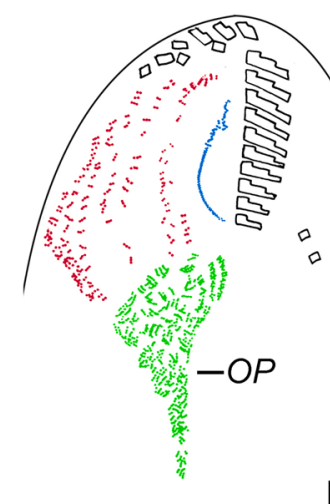

b

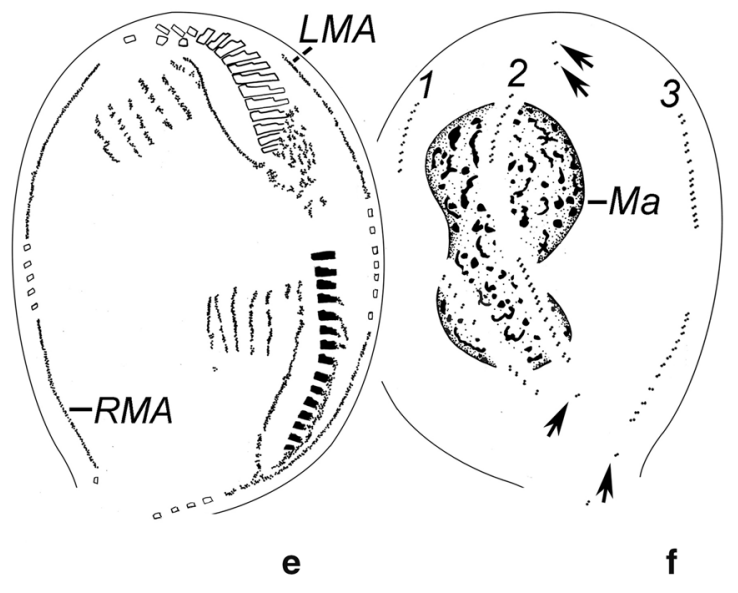

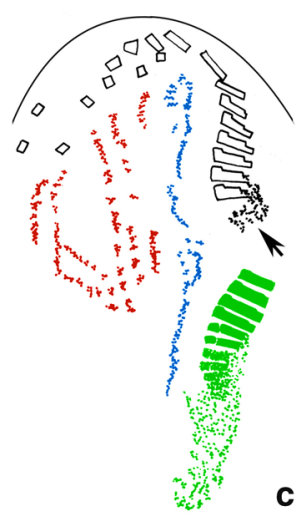
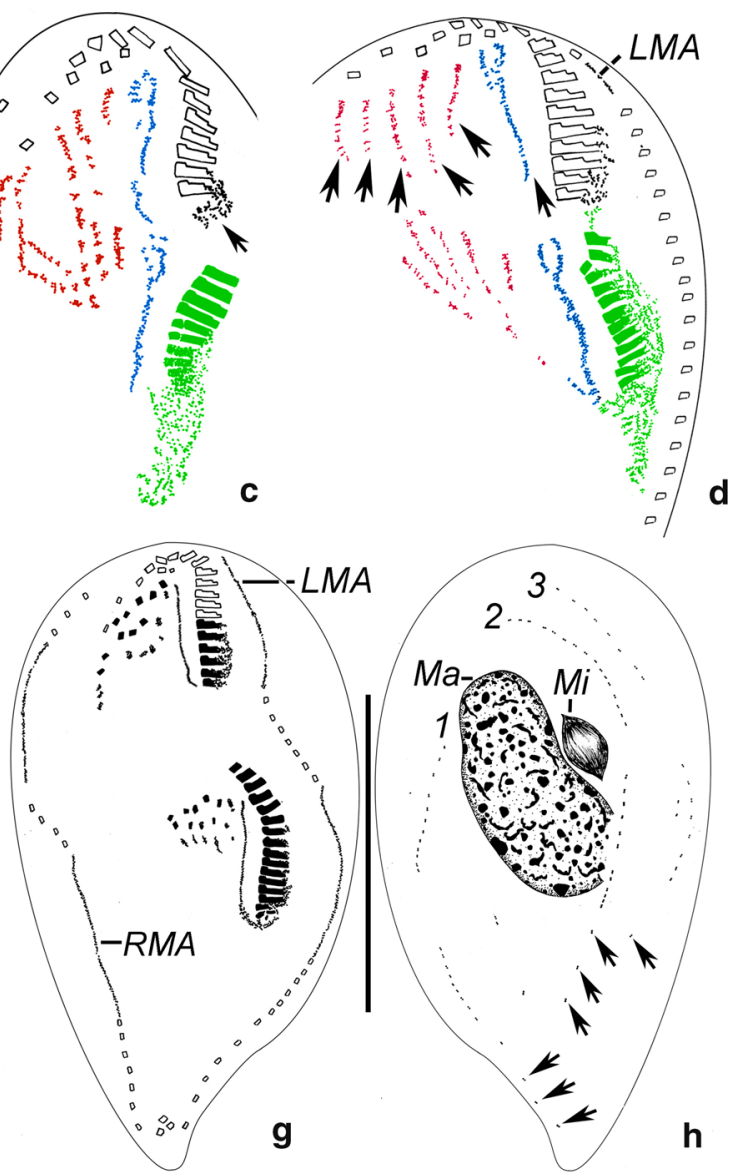

Fig. $3 \mathbf{a}-\mathbf{h}$ Early and middle stages of morphogenesis in Parasincirra sinica n. sp. after protargol staining. $\mathbf{a}$, $\mathbf{b}$ Ventral views of early dividers, showing oral primordium of opisthe and frontoventral-transverse cirral anlagen. Note parental undulating membranes start to dedifferentiate (b). $\mathbf{c}, \mathbf{d}$ Ventral views of later dividers, to show the development of oral primordium, frontoventral-transverse cirral anlagen and undulating membranes anlagen (arrows). Note the dedifferentiation of membranelles at the proximal end of the old adoral zone of membranelles (arrow in c), and the intrakinetally formed anlagen for the marginal rows (d). e- $\mathbf{h}$ Ventral $(e, g)$ and dorsal $(f, h)$ views of middle dividers, to show stretched marginal anlagen and dorsal kineties anlagen, the posterior membranelles of the parental adoral zone of membranelles renewed $(\mathrm{g})$ and the macronuclear nodules fusing into a single mass. Note the old dorsal dikinetids are not absorbed (arrows). OP oral primordium, LMA left marginal anlagen, Ma macronuclear nodules, Mi micronuclei, RMA right marginal anlagen, 1-3 dorsal kineties anlagen 1-3. Scale bars: a, g, $h=60 \mu \mathrm{m}$. The images of this figure we have used are freely available to use 

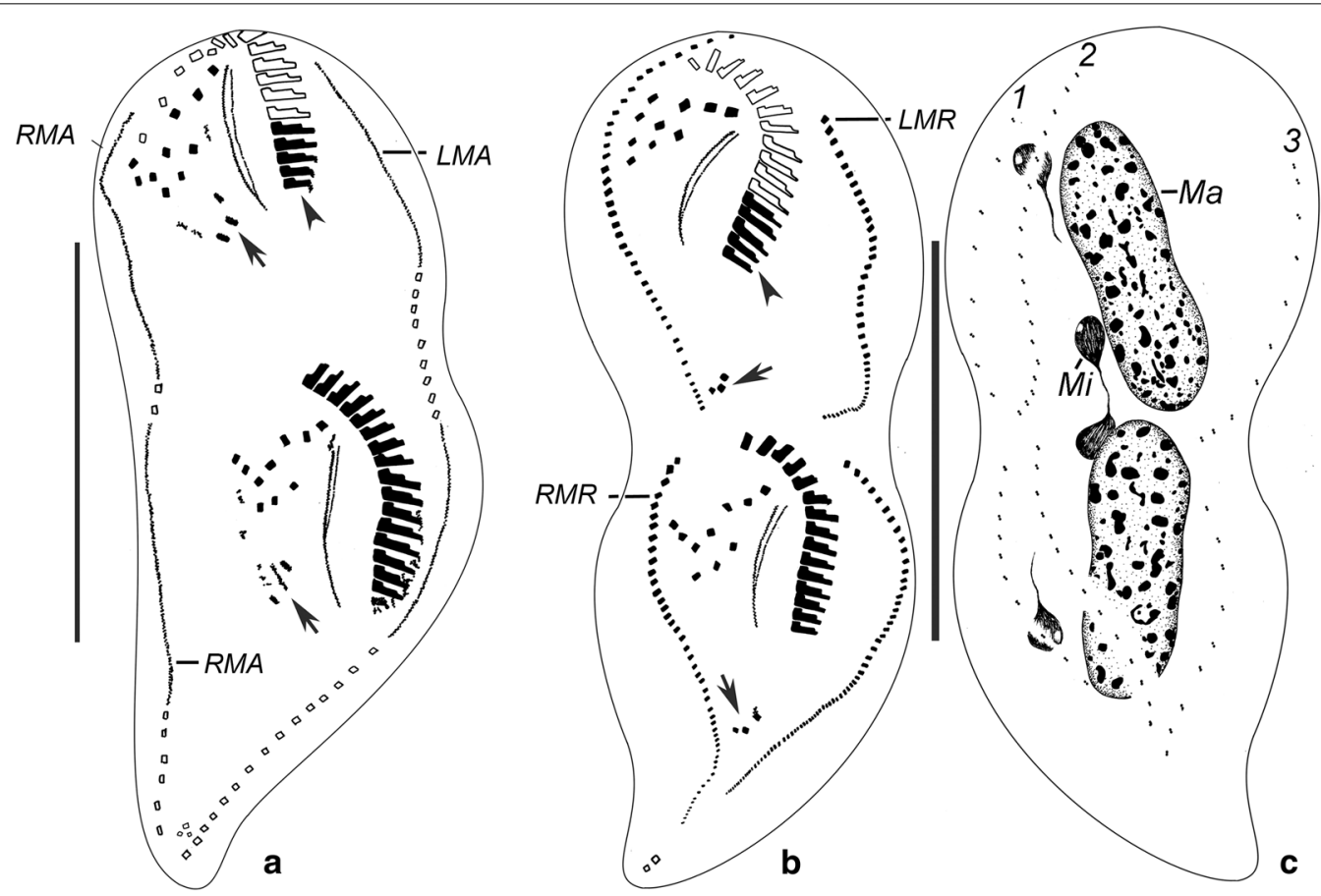

Fig. 4 a-c Late stages of morphogenesis in Parasincirra sinica n. sp. after protargol staining. Ventral (a, b) and dorsal (c) views, to show the frontoventral-transverse cirral anlagen differentiating into cirri, transverse cirri migrating into their final position (arrows), the old adoral zone of membranelles have been rebuilt (arrowheads). LMA left marginal anlagen, LMR left marginal row, RMA right marginal anlagen, RMR right marginal row, Ma macronuclear nodules, Mi micronuclei, 1-3 dorsal kineties anlagen 1-3. Scale bars: $60 \mu \mathrm{m}$. The images of this figure we have used are freely available to use

\section{Division of nuclear apparatus}

The nuclear apparatus divides in the usual way for hypotrichs hence no need to describe this process in detail (Figs. 3f, h, 4c, 5k).

\section{SSU rDNA gene sequence and phylogenetic analyses}

The 18S rDNA gene sequence of Parasincirra sinica n. sp. (GenBank accession number: MN472864) is 1731 bp long and has a G + C content of $45.70 \%$. Phylogenetic trees inferred from the SSU rDNA sequences using two different methods (ML and BI) show similar topologies. Therefore, only the topology of the ML tree is presented with nodal support from both methods (Fig. 7).

Molecular phylogenetic analyses result in a clade containing four polytomies represented by Parasincirra sinica n. sp., two Uroleptoides species and Parabistichella variabilis Jiang et al., 2013 with high support (83\% ML, 1.00 BI, Fig. 7). They also confirm the polyphyly of other amphisiellids including species belonging to the type genus Amphisiella Gourret and Roeser, 1888. The monophyly of the family Amphisiellidae is rejected by the AU test $(\mathrm{p}<0.05)$ based on SSU-rDNA dataset (Table 2).

\section{Discussion}

\section{Comparison with similar genera}

Amphisiellidae were divided into three groups by Berger (2008) [19]. Group I comprises the marine taxa Amphisiella, Caudiamphisiella Berger, 2008, Maregastrostyla Berger, 2008 and Spiroamphisiella Li et al., 2007. Species of these four genera possess a buccal cirrus and a very prominent ACR which commences at about the level of the distal end of the adoral zone of membranelles and terminates beyond the mid-body. Hence the new genus, Parasincirra n. g., can be distinguished from the members of group I.

Group II comprises two genera, i.e., Lamtostyla Buitkamp, 1977 and Uroleptoides Wenzel, 1953, both of which possess a buccal cirrus whereas Parasincirra n. g. lacks a buccal cirrus.

Group III also comprises two genera, i.e. Lamtostylides Berger, 2008 and Paramphisiella Foissner, 1988. Species of these genera possess a buccal cirrus and have only one cirrus (cirrus III/2) left of the ACR. In contrast, 


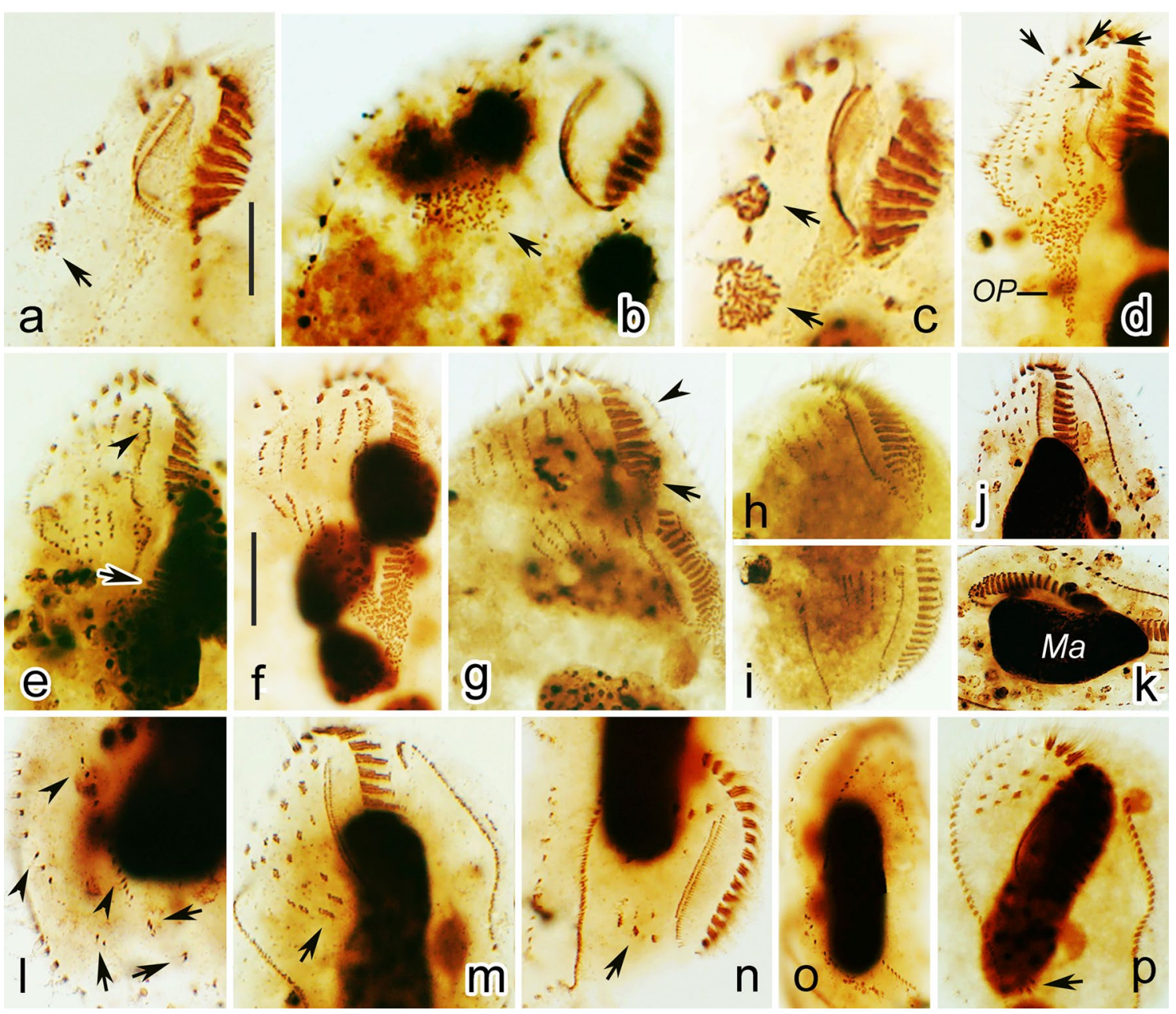

Fig. 5 a-p Photomicrographs of Parasincirra sinica n. sp. during morphogenesis (after protargol staining). a-d Ventral views of early dividers, to indicate the oral primordium (arrows in $\mathrm{a}-\mathrm{c}$ ), the formation of frontoventral-transverse cirral anlagen and undulating membranes starting to dedifferentiate (arrowhead). Note the old frontal cirri remain intact (arrows in d). $\mathbf{e}, \mathbf{f}$ Ventral views of later dividers, to show the oral primordia starting to differentiate into membranelles (arrow), formation of undulating membranes anlagen in the proter (arrowhead), and frontoventral-transverse cirral anlagen starting to separate ( $f$ ). $\mathbf{g}$-i Ventral views of later dividers, to show the dedifferentiation of membranelles at the proximal end of the old adoral zone of membranelles (arrow), the intrakinetally formed anlagen for the marginal rows (arrowhead), and stretched marginal anlagen and frontoventral-transverse cirral anlagen ( $h, i)$. j-IVentral $(j)$ and dorsal $(k, l)$ views of a middle divider, to show frontoventral-transverse cirral anlagen differentiating into cirri (j), dorsal kineties anlagen (arrowheads), the old dorsal dikinetids (arrows) and the macronuclear nodules fusing into a single mass (k). $\mathbf{m}, \mathbf{n}$ Ventral views of a late divider, arrows show transverse cirri migrating into their final positions in the opisthe $(\mathrm{m})$ and proter (n). Note the undulating membranes anlagen longitudinally splitting into parorals and endorals. o Dorsal view, to show the newly formed dorsal kineties. $\mathbf{p}$ Ventral view, to demonstrate transverse cirri (arrow) migrating into their final positions. Scale bars: $15 \mu \mathrm{m}$

Parasincirra n. g. has no buccal cirrus and one frontoventral cirrus left of the ACR.

Six genera, namely Afroamphisiella Foissner et al., 2002, Cossothigma Jankowski, 1978, Hemisincirra Hemberger, 1985, Mucotrichidium Foissner et al., 1990, Terricirra Berger \& Foissner, 1989 and Tetrastyla Schewiakoff, 1892, are incertae sedis in Amphisiellidae [19]. With reference to the general infraciliature, Hemisincirra resembles Parasincirra n. g., however, the type
Table 2 Approximately unbiased (AU) test results

\begin{tabular}{|c|c|c|c|c|}
\hline Datasets & $\begin{array}{l}\text { Topology } \\
\text { constraints }\end{array}$ & $\begin{array}{l}\text { - InL } \\
\text { (likelihood) }\end{array}$ & $\mathrm{AU}(P)$ & Conclusion \\
\hline \multirow[t]{2}{*}{ SSU-rDNA } & Unconstrained & 8986.1376 & 1.000 & - \\
\hline & Amphisiellidae ${ }^{a}$ & 9053.5857 & $5 e-005$ & Rejected \\
\hline
\end{tabular}

Significant differences $(P$ value $<0.05)$ between the best maximum likelihood trees and the best constrained topologies are shown in bold

a Amphisiellidae: includes Uroleptoides, Parasincirra, Lamtostyla and Amphisiella 
species of Hemisincirra has a buccal cirrus (vs. absent in Parasincirra n. g.) [19]. Afroamphisiella can be distinguished from Parasincirra n. g. by the presence (vs. absence) of a buccal cirrus and the absence (vs. presence) of transverse cirri [19]. Cossothigma can be separated from the new genus by its trachelostylid (vs. elliptical to elongate-elliptical) body shape and trachelostylid oral apparatus (vs. in Oxytricha-pattern), and the probable presence (vs absence) of caudal cirri [19]. Mucotrichidium differs from the new genus in possessing a buccal cirrus, postperistomial cirrus and caudal cirri, all of which are absent in Parasincirra n. g. [19]. Terricirra can be separated from Parasincirra n. g. by the presence (vs. absence) of a buccal cirrus, while Tetrastyla can be separated from Parasincirra n. g. by the absence (vs. presence) of parabuccal cirri [19].

Comparison of Parasincirra sinica n. sp. with similar species Species assigned to Hemisincirra have an infraciliature which is very similar to that of Parasincirra sinica n. sp., i.e., three frontal cirri, a short amphisiellid median cirral row, few transverse cirri and lack of caudal cirri.

Considering its somatic ciliature, Parasincirra sinica $\mathrm{n}$. sp. resembles Hemisincirra interrupta and $H$. vermicularis most in that these two species also lack buccal cirrus. Nevertheless $H$. interrupta can be separated from $P$. sinica n. sp. by in having fewer dorsal kineties (1 vs. 3), more macronuclear nodules (about 30 vs. 2-6) and more cirri in the amphisiellid median cirral row (6-8 vs. invariably 4). Hemisincirra vermicularis differs from P. sinica $\mathrm{n}$. sp. in having more macronuclear nodules (about 10 vs. 2-6) and contractile vacuoles (4 vs. 1 ), and fewer dorsal kineties (1 vs. 3) [19].

In terms of the somatic ciliature, Lamtostyla decorata Foissner et al., 2002, L. perisincirra (Hemberger, 1985) Berger and Foissner, 1987, L. islandica Berger and Foissner, 1988, Uroleptoides magnigranulosus (Foissner, 1988) Berger, 2008 and $U$. longiseries (Foissner et al., 2002) Berger, 2008 closely resemble $P$. sinica n. sp. and thus should be compared to the latter. Parasincirra sinica n. sp. differs from Lamtostyla decorata in: (i) its smaller body size in vivo $(90-160 \mu \mathrm{m} \times 20-40 \mu \mathrm{m}$ vs. $100-$ $220 \mu \mathrm{m} \times 20-35 \mu \mathrm{m}$ ); (ii) buccal cirrus and pretransverse cirri absent (vs. present); and (iii) fewer transverse cirri (two to four vs. five to nine) [19].

Discrepancies between Parasincirra sinica n. sp. and Lamtostyla perisincirra include: (i) its larger body size in vivo $(90-160 \mu \mathrm{m} \times 20-40 \mu \mathrm{m}$ vs. $50-80 \mu \mathrm{m} \times 20-30 \mu \mathrm{m})$; (ii) cell outline fusiform (vs. parallel body margins with both ends broadly rounded); (iii) buccal cirrus absent (vs. present); (iv) larger number of cirri in ACR (four vs. six to eight); and (v) cortical granules present (vs. absent) [19].
Parasincirra sinica n. sp. appears to be a close form to Lamtostyla islandica, but the former can be recognised by: (i) larger body size in vivo $(90-160 \mu \mathrm{m} \times 20-40 \mu \mathrm{m}$ vs. $60-80 \mu \mathrm{m} \times 20-25 \mu \mathrm{m}$ ); (ii) cell outline fusiform (vs. parallel body margins with both ends broadly rounded); (iii) buccal cirrus absent (vs. present); (iv) cortical granules present (vs. absent); and (v) arrangement of endoral and paroral (at about same level vs. overlapping only by about half of their length) [19].

Uroleptoides magnigranulosus has a close relationship to P. sinica n. sp. in the SSU rDNA tree (Fig. 7). Parasincirra sinica n. sp., however, can be recognised by: (i) buccal cirrus absent (vs. present) and (ii) having fewer cirri in the ACR (4 vs. 12-19) and transverse cirri (two to four vs. constantly five) [19].

Parasincirra sinica n. sp. can be separated from Uroleptoides longiseries by its lack of a buccal cirrus (vs. present in the latter) and having fewer cirri in the ACR (4 vs. 24-54 in the latter) [19].

\section{Morphogenetic comparison}

One of the most remarkable morphogenetic features in Parasincirra sinica $\mathrm{n}$. sp. is that the rightmost frontoventral row is formed by two anlagen, which is a specific character for amphisiellids and is called the amphisiellid median cirral row. Hitherto, accounts of morphogenesis are available for relatively few amphisiellids and include a wide diversity of processes:

1 The parental adoral zone of membranelles is completely retained in some taxa, e.g. Amphisiella, Lamtostyla, Lamtostylides, Paramphisiella and Hemisincirra inquieta Hemberger, 1985, while it is partly renewed in others, e.g. Parasincirra n. g.;

2 Ventral cirri develop from five (e.g. Lamtostylides and Paramphisiella), six (e.g. Amphisiella, Parasincirra n. g., Spiroamphisiella, Hemisincirra inquieta, Terricirra, Mucotrichidium and most Lamtostyla species) or seven (e.g. Lamtostyla salina Dong, et al., 2016) FVT-anlagen;

3 FVT-anlage II generates the buccal cirrus in several taxa (Amphisiella, Spiroamphisiella, Lamtostyla, Lamtostylides, Paramphisiella, Afroamphisiella, Hemisincirra inquieta, Terricirra and Mucotrichidium) but not in Parasincirra n. g.;

4. The amphisiellid median cirral row is formed by two (in Amphisiella, Hemisincirra inquieta, Parasincirra n. g., Lamtostyla, Lamtostylides, Mucotrichidium and Paramphisiella) or three (in Terricirra and Spiroamphisiella) anlagen;

5 Caudal cirri are formed in some taxa, i.e. Spiroamphisiella, Paramphisiella and Mucotrichidium, but 
not in others, i.e. Amphisiella, Parasincirra n. g., Lamtostyla, Lamtostylides, Afroamphisiella, Hemisincirra inquieta and Terricirra;

6 No transverse cirri are formed in Afroamphisiella and Paramphisiella whereas transverse cirri are formed in Amphisiella, Parasincirra n. g., Lamtostyla, Lamtostylides, Terricirra, Mucotrichidium, Hemisincirra inquieta and Spiroamphisiella [19, 21-23].

\section{Phylogenetic analyses}

Molecular phylogenetic analyses did not resolve the relationship of the four polytomies represented by Parasincirra sinica n. sp., Uroleptoides magnigranulosa, $U$. longiseries and Parabistichella variabilis (Figs. 6, 7). Taxonomically, $P$. sinica $\mathrm{n}$. sp. has the critical character of the family Amphisiellidae, i.e., the ACR that originates from two separate anlagen, and apparently it should be assigned in this family (exactly, group II in Amphisiellidae) $[18,19]$. However, the long ventral row is formed by just a single anlage in Uroleptoides longiseries and Parabistichella variabilis, hence they should not be assigned to Amphisiellidae. Whether Uroleptoides magnigranulosa is correctly assigned to the family Amphisiellidae needs further clarification $[19,24,25]$. The close relationship between these four species is supported by each having three enlarged frontal cirri, one marginal cirral row on each side and cortical granules present. Nevertheless, their close relationship not represented in the SSU rDNA tree might be due to poor taxon sampling.

The phylogenetic relationship between Parasincirra sinica n. sp. and its most morphologically similar genera, Lamtostyla and Hemisinicirra, also needs further investigation due to the remote position of $P$. sinica $\mathrm{n}$. sp. in the SSU rDNA tree and the lack of information of the latter, e.g., the ontogenetic process has not been characterised for the type species of either.

\section{Conclusions}

It is noteworthy that the positions of other amphisiellid species, even members of the type genus Amphisiella, are not well resolved well in the SSU rDNA tree (Fig. 7), which is consistent with previous studies [22, 26, 27]. Members of the Amphisiellidae are placed at two different parts of the phylogenetic tree even though they all possess the critical character of the family, i.e., the development of the ACR from two separate anlagen. Furthermore, the monophyly of the family Amphisiellidae is rejected by the AU test $(\mathrm{p}<0.05)$ based on SSU-rDNA datasets. A composite row, resembling ACR, is formed in Kahliella matisi Vdačný et al., 2010, which belongs to the oxytrichine hypotrichs, and in Hemiholosticha pantanalensis Vdačný and Foissner, 2019, which belongs to the psilotrichid hypotrichs $[28,29]$. These observations indicate that the ACR might be homoplastic. Further studies are needed to clarify the systematic position and evolution of species within the family Amphisiellidae.

\section{Methods}

\section{Sample collection, isolation, and culturing}

Sludge soil samples were collected from the upper $10 \mathrm{~cm}$ layer within a flood drain in Lanzhou $\left(36^{\circ} 3^{\prime} \mathrm{N}\right.$; $103^{\circ} 49^{\prime}$ E), China on 30 April 2017 (Fig. 1). Samples were dried at room temperature (about $24^{\circ} \mathrm{C}$ ) immediately after collection in order to preserve them. Several months later, ciliates were induced to excyst from the soil samples by employing the non-flooded Petri dish method [30]. Ciliate cells were then isolated using micropipettes and nonclonal cultures were established at room temperature in Petri dishes containing mineral water (Nongfu Spring) with rice grains added in order to stimulate the growth of bacteria as food source for the ciliates. We identified only one species, and relied on in vivo morphological characteristics to assure the accuracy of that identification for all downstream analyses, even though we were unable to establish clonal cultures. No other stichotrichid morphotypes were present in the protargol preparations.

\section{Morphology and morphogenetic studies}

Live observations were carried out using bright field and differential interference contrast microscopy (Olympus BX53), photographed using a digital camera and figures were made by Photoshop. Protargol staining was used to reveal the ciliature and the nuclear apparatus [31]. The protargol reagent was synthesized following the protocol of Pan et al. (2013) [32]. Counts and measurements of stained specimens were performed at a magnification of $1000 \times$. Drawings of protargol-stained cells were made with the assistance of a drawing device (camera lucida). To illustrate the changes that occurred during morphogenesis, parental structures are depicted by contour whereas new structures are shaded black [33, 34]. Terminology is according to Berger (2008) [19] and the systematic classification follows Lynn (2008) [18].

\section{DNA extraction, PCR amplification, and gene sequencing}

Single cells of Parasincirra sinica n. sp. were isolated from cultures, washed several times with distilled water using a micropipette in order to remove potential contamination, and then transferred to $1.5 \mathrm{~mL}$ microfuge tubes with a minimum volume of water. DNA extraction was performed with the DNeasy Blood \& Tissue Kit (Qiagen) following the manufacturer's instructions with minor modifications [35, 36]. PCR amplification and sequencing of the SSU rDNA were performed according 


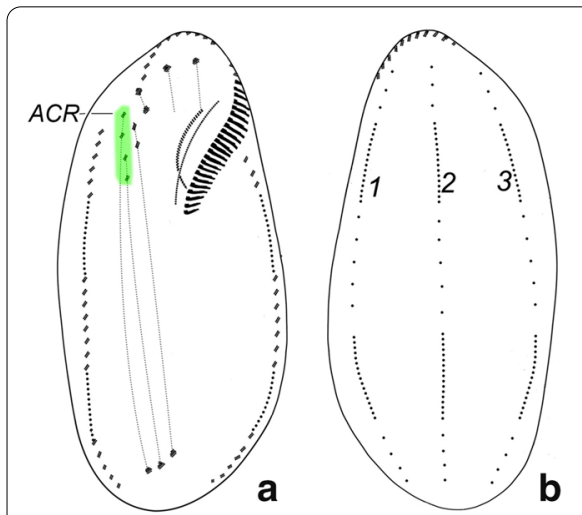

Parasincirra sinica
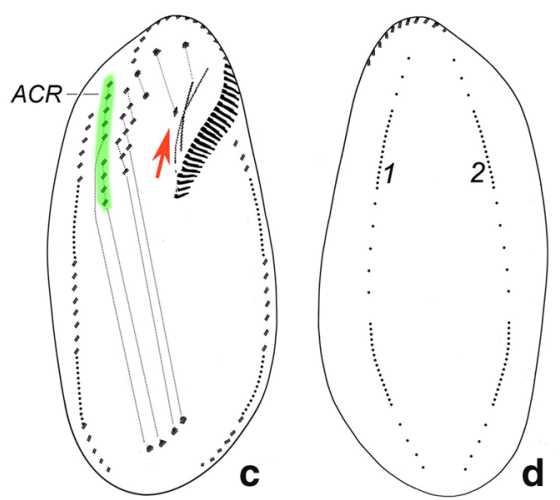

Lamtostyla salina

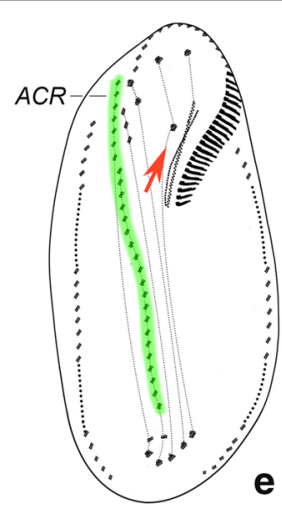

Amphisiella annulata

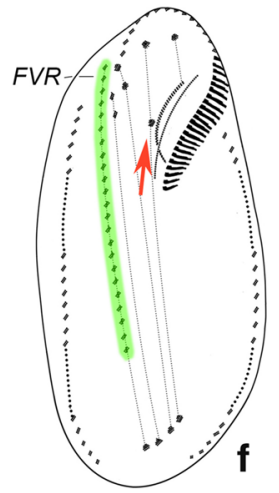

Uroleptoides longiseries

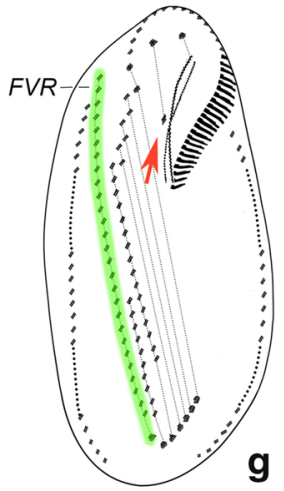

Parabistichella variabilis

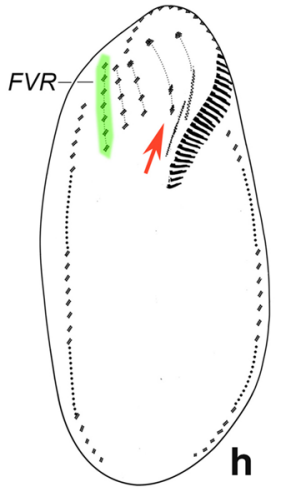

Orthoamphisiella breviseries

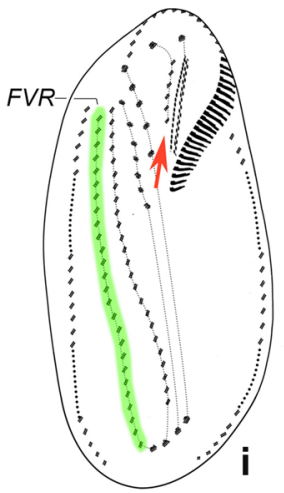

Bistichella cystiforman

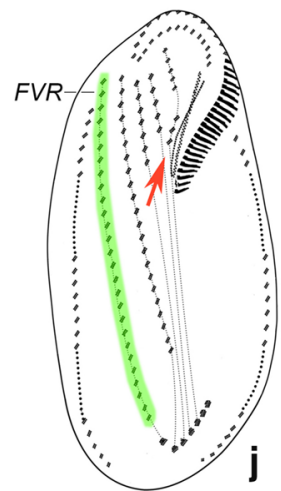

Keronopsis helluo

Fig. 6 a-j Diagram of the infraciliature, and formation patterns of ventral cirri (dotted lines connecting cirri that develop from the same cirral streaks, arrows mark the buccal cirri) (a, c, e-j) and dorsal ciliature (b, d). a Parasincirra sinica. b Parasincirra sinica, Amphisiella annulata, Uroleptoides longiseries, Parabistichella variabilis, Bistichella cystiformans and Keronopsis helluo. c Lamtostyla salina. d Lamtostyla salina and Orthoamphisiella breviseries. e Amphisiella annulata. f Uroleptoides longiseries. $\mathbf{g}$ Parabistichella variabilis. h Orthoamphisiella breviseries. i Bistichella cystiformans. j Keronopsis helluo $[19,22,24-26,47,48]$

to Sheng et al. (2018) [37] using high fidelity Takara Ex Taq DNA polymerase (Takara Ex Taq; Takara Biomedicals) to minimise the possibility of amplification errors. The PCR products were purified using Geneclean (BIO 101 Inc., La Jolla, CA, USA) and sequenced bidirectionally on the ABI 3700 sequencer (GENEWIZ Biotechnology Co., Ltd., Beijing, China).

\section{Phylogenetic analyses and topology testing}

The SSU rDNA sequence of the new species, together with 54 representative taxa downloaded from the GenBank database, were used in the phylogenetic analyses. The final alignment included 54 taxa and 1734 sites, with 446 variable sites and 265 parsimony-information sites. Three oligotrich species (Novistrombidium sinicum Liu et al., 2009, Strombidium cuneiforme Song et al., 2018 and S. apolatum Wilbert et al., 2005) were selected as putative outgroups. All sequences were aligned using the GUIDANCE web server (http://guida nce.tau.ac.il/) [38]. The resulting alignment was manually edited using the program BioEdit 7.0 [39]. Both Maximum likelihood (ML) and Bayesian inference (BI) analyses were performed on the final alignment under the best-fit nucleotide substitution model of GTR $+\Gamma$ that was selected by jModelTest ver. 2.1.7 [40]. The ML analysis was performed using RAxML-HPC2 on XSEDE v8.2.12 on the online server CIPRES Science Gateway [41], with 1000 rapid bootstrap replicates and a subsequent thorough ML search. Bayesian inference was computed with MrBayes on XSEDE 3.2.6 [42], 


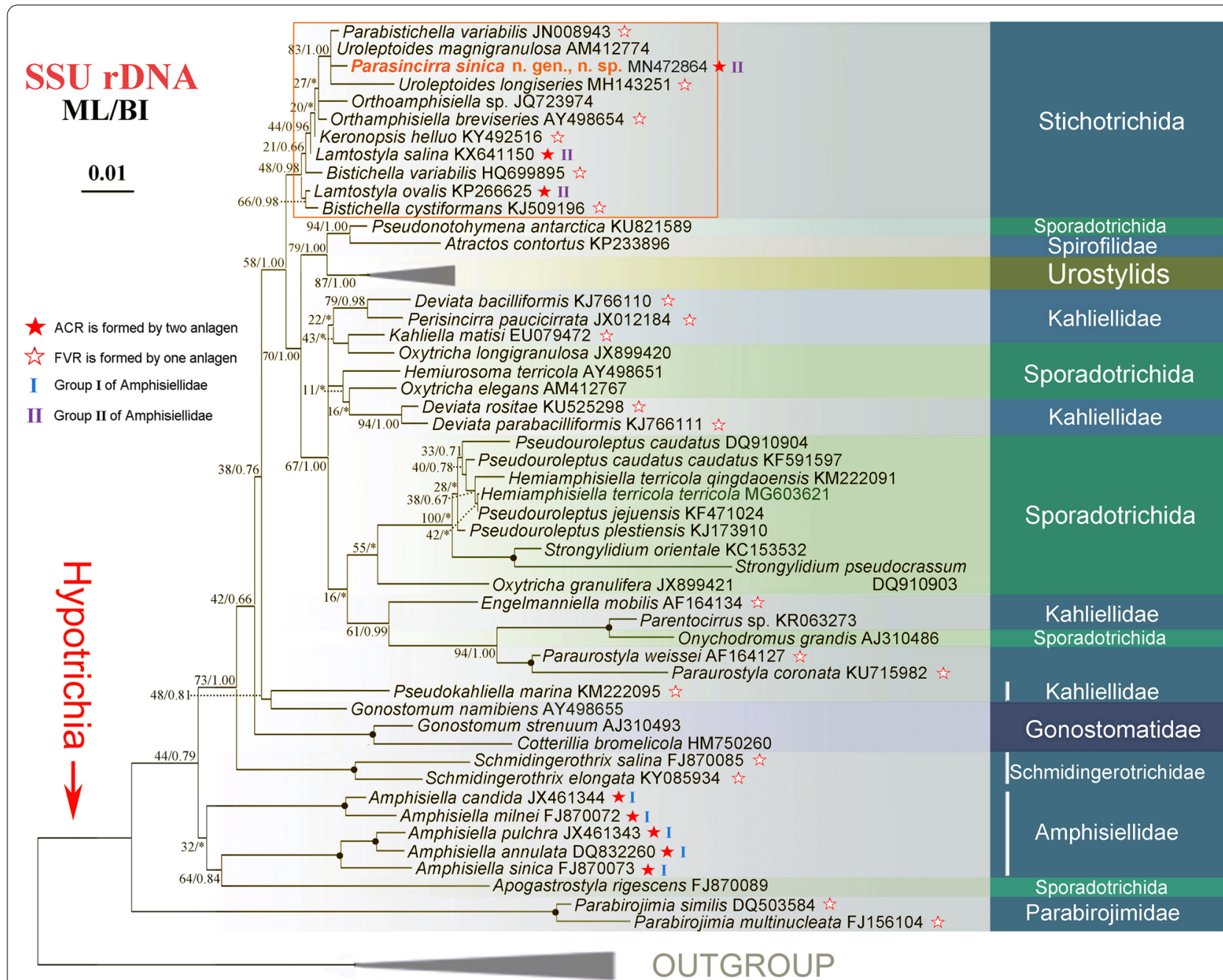

Fig. 7 Maximum likelihood (ML) tree inferred from the SSU rDNA sequences showing the phylogenetic relationships of Parasincirra sinica n. sp. (in bold) and the related species (in rectangular box). Numbers near nodes are bootstrap values for maximum-likelihood and posterior probability values for Bayesian inference (BI). "*" at nodes indicates disagreement between the two methods. Fully supported (100\%/1.00) branches are marked with solid circles. The scale bar corresponds to 0.01 expected substitutions per site

running four Markov chains sampling every 100 generations for a million generations and discarding the first $25 \%$ of trees as burn-in. The majority rule consensus tree was produced from the remaining samples with each node labelled with its posterior probability. SeaView v.4 [43] and MEGA v5 [44] were used to visualise the tree topologies.

The approximately unbiased (AU) test [45] was performed to assess the monophyly of species of the family Amphisiellidae that possess an amphisiellid median cirral row. The constrained ML tree was generated based on SSU rDNA sequences. The site likelihoods for the resulting constrained topology and then on-constrained
ML topology were calculated using PAUP and then analyzed in CONSEL [46].

\section{Abbreviations}

18S rDNA: Small subunit ribosomal DNA; ACR: Amphisiellid median cirral row; AZM: Adoral zone of membranelles; BI: Bayesian inference; bp: Base pairs; FVTanlagen: Frontoventral-transverse cirral anlagen; GC: Guanine-cytosine; ML: Maximum likelihood; n. g.: Novum genus; n. sp.: Novum species.

\section{Acknowledgements}

Many thanks are given to Dr. Jie Huang, Chinese Academy of Sciences, for her help with phylogenetic analyses.

\section{Authors' contributions}

MJ carried out the live observation, protargol impregnation. MJ, ZY, ZT were responsible for DNA amplification and sequencing, and the molecular phylogenetic analyses. Manuscript drafting: MJ, SC, ZY, ZT; Manuscript review 
and editing: SC, ZY, SW. KA.S.AR. Language revision: KASA-R (all authors helped revise the manuscript. All authors read and approved the final manuscript).

\section{Funding}

This work was supported by the Natural Science Foundation of China (Project numbers: 32070428, 31872190), the Researchers Supporting Project number (RSP-2021/7), King Saud University, Riyadh, Saudi Arabia, the Fundamental Research Funds for the Central Universities (201841005) and the Blue Life Breakthrough Program of LMBB of Qingdao National Laboratory for Marine Science and Technology (MS2018NO04). Funding agencies had no role in the design or implementation of this study or in preparation of the manuscript.

\section{Availability of data and materials}

Sequence data are available in GenBank (Accession Numbers: MN472864 has been released). One protargol-stained slide (No. MJY2017043001B) with the holotype specimen and several paratype slides (No. MJY2017043001 A, C) were deposited in the Laboratory of Protozoological Biodiversity and Evolution in Wetland, Shaanxi Normal University, China.

\section{Ethics approval and consent to participate}

Not applicable.

\section{Consent for publication}

Not applicable.

\section{Competing interests}

The authors declare that they have no competing interests.

\section{Author details}

'Institute of Evolution \& Marine Biodiversity, and College of Fisheries, Ocean University of China, Qingdao 266003, China. ${ }^{2}$ Laboratory of Protozoological Biodiversity and Evolution in Wetland, College of Life Sciences, Shaanxi Normal University, Xi'an 710119, China. ${ }^{3}$ College of Life Sciences, Capital Normal University, Beijing 100048, China. ${ }^{4}$ Zoology Department, College of Science, King Saud University, Riyadh 11451, Saudi Arabia. ${ }^{5}$ Laboratory for Marine Biology and Biotechnology, Qingdao National Laboratory for Marine Science and Technology, Qingdao 266003, China.

\section{Received: 19 December 2019 Accepted: 1 December 2020} Published online: 10 February 2021

\section{References}

1. Chen L, Dong J, Wu W, Xin Y, Warren A, Ning Y, et al. Morphology and molecular phylogeny of a new hypotrich ciliate, Anteholosticha songi nov. spec., and an American population of Holosticha pullaster (Müller, 1773) Foissner et al., 1991 (Ciliophora, Hypotrichia). Eur J Protistol. 2020;72:125646

2. Luo X, Huang JA, Li L, Song W, Bourland WA. Phylogeny of the ciliate family Psilotrichidae (Protista, Ciliophora), a curious and poorly-known taxon, with notes on two algae-bearing psilotrichids from Guam, USA. BMC Evolut Biol. 2019:19(1):125

3. Kaur H, Negi SSRK, Kamra K. Morphological and molecular characterization of Neogastrostyla aqua nov. gen., nov. spec. (Ciliophora, Hypotrichia) from River Yamuna, Delhi; comparison with Gastrostyla-like genera. Eur J Protistol. 2019:68:68-79

4. Park KM, Jung JH, Kim JH, Min GS, Kim S. Morphology, morphogenesis, and molecular phylogeny of a new freshwater ciliate, Gonostomum jangbogoensis n. sp. (Ciliophora, Hypotricha), from Victoria Land, Antarctica. Eur J Protistol. 2020:73:125669.

5. Luo X, Yan Y, Shao C, Al-Farraj SA, Bourland WA, Song W. Morphological, ontogenetic and molecular data support strongylidiids as being closely related to Dorsomarginalia (Protozoa, Ciliophora) and reactivation of the family Strongylidiidae Fauré-Fremiet, 1961. Zool J Linn Soc. 2018:184:237-54

6. Bharti D, Kumar S, La Terza A, Chandra K. Morphology and ontogeny of Tetmemena pustulata indica nov. subspec. (Ciliophora, Hypotricha), from the Thane Creek, Mumbai, India. Eur J Protistol. 2019;71:125629.
7. Kim KS, Min GS. Morphology and molecular phylogeny of Oxytricha seokmoensis sp. nov. (Hypotrichia: Oxytrichidae), with notes on its morphogenesis. Eur J Protistol. 2019;71:125641.

8. Xu W, Wang Y, Cheng T, Y Y Y, El-Serehy H, Al-Farraj SA, et al. Reevaluation of the 'well-known' Paraurostyla weissei complex, with notes on the ontogenesis of a new Paraurostyla species (Ciliophora, Hypotrichia). Eur J Protistol. 2020:73:125672.

9. Dong J, Li L, Fan X, Ma H, Warren A. Two Urosoma species (Ciliophora, Hypotrichia): a multidisciplinary approach provides new insights into their ultrastructure and systematics. Eur J Protistol. 2020;72:125661.

10. Wang Y, Jiang Y, Liu Y, Li Y, Katz LA, Gao F, et al. Comparative studies on the polymorphism and copy number variation of $\mathrm{mtSSU}$ rDNA in ciliates (Protista, Ciliophora): implications for phylogenetic, environmental, and ecological research. Microorganisms. 2020;8:316.

11. Lian C, Luo X, Warren A, Zhao Y, Jiang J. Morphology and phylogeny of four marine or brackish water spirotrich ciliates (Protozoa, Ciliophora) from China, with descriptions of two new species. Eur J Protistol. 2020;72:125663.

12. Jung JH, Berger H. Monographic treatment of Paraholosticha muscicola (Ciliophora, Keronopsidae), including morphological and molecular biological characterization of a brackish water population from Korea. Eur J Protistol. 2019:68:48-67.

13. Wang J, Zhao Y, Lu X, Lyu Z, Warren A, Shao C. Does the Gonostomumpatterned oral apparatus in Hypotrichia carry a phylogenetic signal? Evidence from morphological and molecular data based on extended taxon sampling using three nuclear genes (Ciliophora, Spirotrichea). Sci China Life Sci. 2020. https://doi.org/10.1007/s11427-020-1667-3.

14. Zhang T, Dong J, Cheng T, Duan L, Shao C. Reconsideration of the taxonomy of the marine ciliate Neobakuella aenigmatica Moon et al., 2019 (Protozoa, Ciliophora, Hypotrichia). Mar Life Sci Technol. 2020;2:97-108.

15. Song W, Shao C. Ontogenetic patterns of Hypotrich ciliates. Beijing: Science Press; 2017 (in Chinese).

16. Lyu Z, Wang J, Huang JA, Warren A, Shao C. Multigene-based phylogeny of Urostylida (Ciliophora, Hypotrichia), with establishment of a novel family. Zool Scr. 2018;47:243-54

17. Fernandes NM, Schrago CG. A multigene timescale and diversification dynamics of Ciliophora evolution. Mol Phylogenet Evol. 2019;139:106521

18. Lynn DH. The ciliated protozoa: characterization, classification and guide to the literature. 3rd ed. Dordrecht: Springer; 2008.

19. Berger H. Monograph of the Amphisiellidae and Trachelostylidae (Ciliophora, Hypotricha). Monogr Biol. 2008;88:1-737.

20. Lu X, Huang JA, Shao C, Berger H. Morphology, cell-division, and phylogeny of Schmidingerothrix elongata spec. nov. (Ciliophora, Hypotricha), and brief guide to hypotrichs with Gonostomum-like oral apparatus. Eur J Protistol. 2018;62:24-42.

21. Chen X, Shao C, Lin X, Clamp JC, Song W. Morphology and molecular phylogeny of two new brackish-water species of Amphisiella (Ciliophora, Hypotrichia), with notes on morphogenesis. Eur J Protistol. 2013:49:453-66.

22. Dong J, Lu X, Shao C, Huang J, Al-Rasheid KAS. Morphology, morphogenesis and molecular phylogeny of a novel saline soil ciliate, Lamtostyla salina n. sp. (Ciliophora, Hypotricha). Eur J Protistol. 2016;56:219-31.

23. Li L, Zhao X, Ji D, Hu X, Al-Rasheid KAS, Al-Farraj SA, et al. Description of two marine amphisiellid ciliates, Amphisiella milnei (Kahl, 1932) Horváth, 1950 and A. sinica sp. nov. (Ciliophora: Hypotrichia), with notes on their ontogenesis and SSU rDNA-based phylogeny. Eur J Protistol. 2016:54:59-73.

24. Wang J, Li J, Qi S, Warren A, Shao C. Morphogenesis and molecular phylogeny of a soil cliate Uroleptoides longiseries (Foissner, Agatha and Berger, 2002) Berger 2008 (Ciliophora, Hypotrichia). J Eukaryot Microbiol. 2019;66:334-42.

25. Jiang J, Huang J, Li L, Shao C, Al-Rasheid KAS, Al-Farraj SA, et al. Morphology, ontogeny, and molecular phylogeny of two novel bakuellid-like hypotrichs (Ciliophora: Hypotrichia), with establishment of two new genera. Eur J Protistol. 2013;49:78-92.

26. Fan Y, Hu X, Gao F, Al-Farraj SA, Al-Rasheid KAS. Morphology, ontogenetic features and SSU rRNA gene-based phylogeny of a soil ciliate, Bistichella cystiformans spec. nov. (Protista, Ciliophora, Stichotrichia). Int I Syst Evol Microbiol. 2014;64:4049-60.

27. Luo X, Yi Z, Gao F, Pan Y, Al-Farraj SA, Warren A. Taxonomy and molecular phylogeny of two new brackish hypotrichous ciliates, with the 
establishment of a new genus (Protozoa, Ciliophora). Zool J Linn Soc. 2017;179:475-91.

28. Vd’ačný P, Tirjaková E, Tóthová T, Pristaš P, Javorský P. Morphological and phylogenetical studies on a new soil hypotrich ciliate: Kahliella matisi spec. nov. (Hypotrichia, Kahliellidae). Eur J Protistol. 2010;46:319-33.

29. Vdačný P, Foissner W. Morphology and ontogenesis of Hemiholosticha pantanalensis nov. spec. (Ciliophora, Hypotrichia, Psilotrichidae). Acta Protozool. 2019;58:93-113.

30. Foissner W. An update of 'basic light and scanning electron microscopic methods for taxonomic studies of ciliated protozoa.' Int I Syst Evol Microbiol. 2014;64:271-92.

31. Wilbert N. Eine verbesserte Technik der Protargolimprägnation für Ciliaten. Mikrokosmos. 1975;64:171-9.

32. Pan X, Bourland WA, Song W. Protargol synthesis: an in-house protocol. J Eukaryot Microbiol. 2013;60:609-14.

33. Wang J, Li J, Shao C. Morphology, morphogenesis, and molecular phylogeny of a novel saline soil ciliate, Heterourosomoida sinica n. sp. (Ciliophora, Hypotrichia). Eur J Protistol. 2020;73:125666.

34. Shao C, Hu C, Fan Y, Warren A, Lin X. Morphology, morphogenesis and molecular phylogeny of a freshwater ciliate, Monomicrocaryon euglenivorum euglenivorum (Ciliophora, Oxytrichidae). Eur J Protistol. 2019:68:25-36.

35. Gao F, Gao S, Wang P, Katz LA, Song W. Phylogenetic analyses of cyclidiids (Protista, Ciliophora, Scuticociliatia) based on multiple genes suggest their close relationship with thigmotrichids. Mol Phylogenet Evol. 2014;75:219-26.

36. Wang Y, Wang C, Jiang Y, Katz LA, Gao F, Yan Y. Further analyses of variation of ribosome DNA copy number and polymorphism in ciliates provide insights relevant to studies of both molecular ecology and phylogeny. Sci China Life Sci. 2019;62:203-14.

37. Sheng Y, He M, Zhao F, Shao C, Miao M. Phylogenetic relationship analyses of complicated class Spirotrichea based on transcriptomes from three diverse microbial eukaryotes: Uroleptopsis citrina, Euplotes vannus and Protocruzia tuzeti. Mol Phylogenet Evol. 2018;129:338-45.

38. Penn O, Privman E, Ashkenazy H, Landan G, Graur D, Pupko T. GUIDANCE: a web server for assessing alignment confidence scores. Nucleic Acids Res. 2010;38:W23-8.
39. Hall TA. BioEdit: a user-friendly biological sequence alignment editor and analysis program for Windows 95/98/NT. Nucleic Acids Symp Ser. 1999:41:95-8.

40. Darriba D, Taboada GL, Doallo R, Posada D. JModelTest 2: more models, new heuristics and parallel computing. Nat Methods. 2012;9:772.

41. Miller MA, Pfeiffer W, SchwartzT. Creating the CIPRES Science Gateway for inference of large phylogenetic trees. In: 2010 gateway computing environments workshop (GCE), New Orleans. 2010. p. 1-8.https://doi. org/10.1109/GCE.2010.5676129.

42. Ronquist F, Teslenko M, van der Mark P, Ayres DL, Darling A, Höhna S, et al. MrBayes 3.2: efficient Bayesian phylogenetic inference and model choice across a large model space. Syst Biol. 2012;61:539-42.

43. Gouy M, Guindon S, Gascuel O. SeaView version 4: a multiplatform graphical user interface for sequence alignment and phylogenetic tree building. Mol Biol Evol. 2010;27:221-4.

44. Tamura K, Peterson D, Peterson N, Stecher G, Nei M, Kumar S. MEGA5: molecular evolutionary genetics analysis using maximum likelihood, evolutionary distance, and maximum parsimony methods. Mol Biol Evol. 2011;28:2731-9.

45. Shimodaira H. An approximately unbiased test of phylogenetic tree selection. Syst Biol. 2002;51:492-508.

46. Shimodaira H, Hasegawa M. Consel: for assessing the confidence of phylogenetic tree selection. Bioinformatics. 2001;17:1246-7.

47. Park KM, Chae N, Jung JH, Min GS, Kim S, Berger H. Redescription of Keronopsis helluo Penard, 1922 from Antarctica and Paraholosticha pannonica Gellért and Tamás, 1959 from Alaska (Ciliophora, Hypotricha). Eur J Protistol. 2017;60:102-18.

48. Berger H. Monograph of the Gonostomatidae and Kahliellidae (Ciliophora, Hypotricha). Monogr Biol. 2011;91:1-741.

\section{Publisher's Note}

Springer Nature remains neutral with regard to jurisdictional claims in published maps and institutional affiliations.

Ready to submit your research? Choose BMC and benefit from:

- fast, convenient online submission

- thorough peer review by experienced researchers in your field

- rapid publication on acceptance

- support for research data, including large and complex data types

- gold Open Access which fosters wider collaboration and increased citations

- maximum visibility for your research: over $100 \mathrm{M}$ website views per year

At BMC, research is always in progress.

Learn more biomedcentral.com/submissions 